\title{
The Synergy of Teachers and Parents Efforts in Improving Students Creativity in Network Learning
}

\author{
Yuli Setiawati ${ }^{1}$, Ristiana Dyah Purwandari ${ }^{2}$ \\ $\left\{\right.$ yulisetiaww@gmail.com ${ }^{1}, \underline{\text { ristianadyah@yahoo.com }}{ }^{2}$ \} \\ ${ }^{1}$ SDN 1 Kracak \\ ${ }^{2}$ Universitas Muhammadiyah Purwokerto
}

\begin{abstract}
The purpose of this study was to determine the efforts of teachers and parents in increasing students' creativity in online learning at SDN 1 Kracak. The method used inthis study is a qualitative descriptive method. Data obtained by interview, observation and documentation then analyzed. Based on the results of the research that has been done, it shows that the synergy of the efforts of teachers and parents in online learning can increase students' creativity.
\end{abstract}

Keywords: Teachers and Parents Efforts, Creativity, Network Learning

\section{Introduction}

The COVID-19 pandemic, which began in early 2020, continues to affect education today. The COVID-19 pandemic has influenced almost every country in the world, and it has adversely impacted almost every sector, including the economy, education, agriculture, tourism, health, and so on [1]. The impact of this pandemic is recommended by the community, as well as students for the first time as a whole learning in Indonesia carries out online learning (on the network) so that students continue to study from home, this is in accordance with the circular letter of the Minister of Education and Culture of the Republic of Indonesia No. 3 of 2020 concerning online learning [2].

The problem that arises when online learning is carried out is that not all knowledge can be channeled optimally, so creative attitudes and behaviors are needed to encourage students to feel interested and challenged to be creatively busy [3]. This is in line so that students will still be able to keep up with technological, economic and educational developments because the present and the future require someone to think and be creative, where with creativity in a person they can carry on their lives and advance the nation. Then, creativity allows humans to improve their quality of life. In this era of development, it is undeniable that the welfare and glory of our society and our country depend on creative contributions, in the form of new ideas, new inventions, and new technologies from members of the community [4]. To achieve this, it is necessary to cultivate creative attitudes and behavior from an early age, so that children will not only become consumers of knowledge, but are able to produce new knowledge, not only become job seekers, but are able to create new jobs (entrepreneurs).

Creativity can be defined as the ability to think, behave, and act about something in a new and unusual way to solve various problems, so that it can produce original and useful solutions [5]. As a superior competence, human creative actions are not solely for the benefit of humans in utilizing learning resources or the potential of natural resources. Creativity is also directed for the sake of sustainability or the preservation of human life with the environment as its carrying capacity. 
The existence of this pandemic has an impact on learning activities, the teacher's efforts in learning are not fully implemented such as face-to-face learning [3]. The creativity of teachers in carrying out online learning activities and parents who are always active in accompanying their children to study at home will help students actively and creatively participate in learning from home. Based on the above context, the researcher will conduct research on how to implement "Synergy Efforts of Teachers and Parents in Improving Student Creativity in Online Learning at SDN 1 Kracak". learning. so that the material presented can be more interesting.

\section{Literature Review}

\subsection{Understanding the Role of Teachers and the Role of Parents}

Teachers in developing children's creativity is one of the steps to create a quality and competitive next generation of the nation, namely teachers are responsible for implementing the learning system so that it works well [6]. Teachers hold various types of efforts that inevitably must be carried out as a teacher [7]. According to Pullias and Young, there are several roles of teachers in learning, namely: Teachers as educators, teachers, mentors, trainers, advisors, innovators, a model and role model, a person, and as an evaluator. As an educator, a teacher has a very important role in developing student creativity, because education in schools is expected to stimulate creative-productive thinking, attitudes, and behavior, in addition to logical thinking and reasoning [8].

Munandar explained that wise parents can distinguish between paying too much or too little attention, between giving children the opportunity to develop their talents and interests and creativity and putting pressure on them to achieve as much as possible [8]. These conditions can be created if parents themselves show an interest in certain hobbies, to read and provide enough varied reading materials.

Parents create a home environment where parents participate in intellectual activities, or in games that increase children's thinking power, such as playing checkers, playing chess and so on. Then, they create an environment where parents invite their children to sing, draw, paint, play musical instruments. So, it's not just an intellectual activity. And without spending a lot of money, parents can make the house a kind of "creativity center" for children, where children alone or with some other friends can be creatively busy. For this reason, a space (not too big) can be provided with a supply of various materials that stimulate children to be creative while being creative, such as various colored paper, books, simple tools, leftover cardboard, bottles, plastic, paint, crayons, musical instruments and so on [9].

\subsection{Study of Creativity Theory}

Creativity is one of the human abilities that is essential in life. This ability is primarily based on intellectual abilities such as intelligence, talent, and learning outcomes skills, but it is also supported by affective and psychomotor factors [5]. According to Munandar, creativity is the ability to create new combinations based on existing data, information, or elements [8]. All of a person's life experiences are referred to as data, information, or elements that exist in the sense of pre-existing. All of the knowledge he has gained during his school years, as well as what he has learned in his family and society.

From a young age, children have the ability to be creative. When asked about unusual uses of everyday objects, they can provide a variety of responses. An example of a question "brick can be used for anything?" revolved around "to build walls, ponds, and seats," so the answers, while numerous, did not differ because all of them involved bricks as a building material. This demonstrates not only fluency in thinking (the ability to provide numerous answers), but also 
flexibility (the ability to provide a variety of answers and see problems from variousperspectives) $[8]$.

\section{Research Methods}

This research was conducted using a qualitative approach to dig deeper information about the efforts of teachers and parents in developing students' creativity through online learning. Furthermore, Cresswell et al. states that qualitative research means the process of exploring and understanding the meaning of individual and group behavior, describing social problems or humanitarian problems [10]. The research process includes making research questions and procedures that are temporary, collecting in participant settings, analyzing data inductively, building partial data into themes, and then providing interpretations of the meaning of the data. The final activity is to make reports into a flexible structure [7]. Interviews in this study I focused on teachers and parents. The research location is at SDN 1 Kracak, Ajibarang District,Banyumas Regency, Central Java 53163.The data collection technique used in qualitative research is direct observation to the object of research, researchers observe facts about the efforts of teachers and parents in developing students' creativity through online learning and in-depth interviews. Researchers get direct information from teachers and parents about the efforts of teachers and parents in developing students' creativity through online learning and documentation.

The stages in data analysis that the researchers carried out were in accordance with the theory of Miles, Huberman, and Saldana, namely analyzing data using three steps, namely (1) data reduction: data reduction is the process of selecting, focusing on simplification, abstracting, and transforming "rough" data." that emerged from the written notes at the research site [11]. This data reduction takes place continuously during qualitative-oriented research activities, (2) data display (data display): The data presentation here is a collection of information that provides the possibility of drawing conclusions and taking action, (3) drawing conclusions or verification: in this third process The researcher begins to search for objects, noting regularities, patterns, explanations, possible configurations of causal pathways, and propositions.

\section{Result And Discussion}

The results of the study indicate that there is an influence that shows the synergy between the efforts of teachers and parents to increase students' creativity in online learning at SDN 1 Kracak. This is based on observations and in-depth interviews that have been carried out by the author with the Class IV teacher and the Grade VI teacher. Efforts were made to increase students' creativity by using the Project Base Learning (PBL) method and the Interactive Quiz Method. The learning process can be seen at Table 1 . 
Table 1. The learning example of the sinergy of efforts of teachers and parents to increase the creativity of students:

\begin{tabular}{|c|c|c|c|}
\hline No & Teacher Efforts & Parents Efforts & Creativity Students \\
\hline 1 & $\begin{array}{l}\text { Using the Learning method Project Based } \\
\text { Learning (PBL) learning methods in class IV } \\
\text { Theme } 7 \text { material for making collages. } \\
\text { The teacher conveys material to Class IV Theme } 7 \\
\text { students with the material to make collages the } \\
\text { learning method used is Project Based Learning } \\
\text { (PBL). Delivery of liaison material using chat in } \\
\text { the Class VI group WA and learning videos as the } \\
\text { delivery of the material. } \\
\text { Learning steps : } \\
\text { a. The teacher opens the lesson with greetings } \\
\text { through Group Chat, } \\
\text { "Assalamualaikum Warrahmatullahi } \\
\text { Wabarakatuh" } \\
\text { Good morning children, may the children } \\
\text { always be healthy and in the protection of } \\
\text { Allah. } \\
\text { "Before learning begins, let's pray together." } \\
\text { The teacher and students pray and then continue } \\
\text { with the teacher asking questions to }\end{array}$ & $\begin{array}{l}\text { a. Guide, } \\
\text { Parent guide children when they get } \\
\text { information about the tasks to be done, } \\
\text { then parents accompany children by } \\
\text { watching learning videos in the class } \\
\text { group WA, so that they can guide } \\
\text { children so that they can work on } \\
\text { assignments to be more focused. Then } \\
\text { ask the child about the video: } \\
\text { "Son, from the video that you have } \\
\text { watched, have you understood it, if } \\
\text { there is someone who doesn't } \\
\text { understand what part?" } \\
\text { b.Facilitate } \\
\text { Parents provide what children need } \\
\text { according to their learning tasks, such } \\
\text { as materials and tools to make collage } \\
\text { products, namely scissors, paper, glue, } \\
\text { and other materials. }\end{array}$ & $\begin{array}{l}\text { Students can make various collage } \\
\text { model products based on objects and } \\
\text { items that are around by pouring their } \\
\text { ideas and students' creativity. For } \\
\text { example, to be able to make beautiful } \\
\text { collage art, the creativity that appears } \\
\text { in students is: } \\
\text { a. Using varied materials regardless of } \\
\text { what the teacher says } \\
\text { b. Students make collages with } \\
\text { different animal themes than usual. } \\
\text { If students usually make animal } \\
\text { themes with animals that are around } \\
\text { their environment, then there are } \\
\text { students who make Tyrex dinosaur } \\
\text { animal themes. This shows that } \\
\text { their imagination is high and } \\
\text { creative so that they can pour } \\
\text { through the task of making collage } \\
\text { products. }\end{array}$ \\
\hline
\end{tabular}




\begin{tabular}{|c|c|c|}
\hline $\begin{array}{l}\text { students before learning begins with the aim of } \\
\text { stimulating the stimulus of students regarding } \\
\text { the learning that will be carried out that day. } \\
\text { "Kids, do any of the children know what the } \\
\text { technique of making works with the sticking } \\
\text { technique is called?" } \\
\text { From the questions submitted by the teacher, } \\
\text { the children gave various answers, some called } \\
\text { mosaics, collages, montages, and many others. } \\
\text { The teacher explains that today we will learn } \\
\text { about the technique of pasting a collage and } \\
\text { the teacher explains what is meant by collage. } \\
\text { "Collage is a two-dimensional application } \\
\text { creation made by cutting and pasting" } \\
\text { b. Planning a project, where the teacher provides } \\
\text { information about the project design for } \\
\text { making collages using learning videos }\end{array}$ & $\begin{array}{l}\text { "So, after you see the ways through the } \\
\text { video. What can I provide, son, for you } \\
\text { to make the collage?" } \\
\text { c. Provide opportunities for children to } \\
\text { express what they want. } \\
\text { When the child will make a collage } \\
\text { product. We ask the children when } \\
\text { they are going to make a collage, the } \\
\text { child will make a theme about what, } \\
\text { then what parents can help with. } \\
\text { Activities like this will make students } \\
\text { feel comfortable because there is } \\
\text { support from parents and they are } \\
\text { confident to be able to make collage } \\
\text { products. } \\
\text { "So what theme will you make the } \\
\text { collage use?" } \\
\text { After that, the child conveys what he } \\
\text { wants } \\
\text { d. Motivate children and give praise to } \\
\text { the products produced. } \\
\text { So that children are more enthusiastic } \\
\text { as parents to keep motivating, positive } \\
\text { affirmations that you can make your } \\
\text { own with the ideas they want and give } \\
\text { rewards or praise when the child is } \\
\text { working and when the results of }\end{array}$ & $\begin{array}{l}\text { c. Students can mix and match } \\
\text { between animal and plant themes } \\
\text { into one collage product, not } \\
\text { choosing only one of them. } \\
\text { d. In finishing the collage product, } \\
\text { when ordinary students finish } \\
\text { making a collage, just take a photo } \\
\text { and send it, then some students to } \\
\text { make it look better and attractive in } \\
\text { the collage product are added a } \\
\text { frame and some are laminated this } \\
\text { is done with the aim of the product } \\
\text { being durable and can be displayed } \\
\text { or displayed when it has been } \\
\text { assessed by the teacher. }\end{array}$ \\
\hline
\end{tabular}




\begin{tabular}{|l|l|l|}
\hline KBdP Kelas 4 Sekolah Dasar (Membuat & $\begin{array}{l}\text { making the collage have been } \\
\text { completed. } \\
\text { "It's good son, you can make it well" } \\
\text { e. Communicate with the teacher if there } \\
\text { is something the children and parents } \\
\text { do not understand. } \\
\text { This is done to bridge communication } \\
\text { between children and teachers when } \\
\text { there are children who still do not } \\
\text { understand. So parents provide } \\
\text { solutions for children to directly ask } \\
\text { the teacher. }\end{array}$ \\
$\begin{array}{l}\text { In the WA class IV group, the teacher sends a } \\
\text { video lesson about collage techniques, how to } \\
\text { make collage art, and what are the uses of } \\
\text { collage techniques. After students watch it } \\
\text { with the aim that students can understand it. } \\
\text { The teacher then provides reinforcement of } \\
\text { information about the video using voice notes } \\
\text { and WA chat. } \\
\text { "How are the children, do you understand yet } \\
\text { about the collage technique that is exemplified } \\
\text { through the video?" } \\
\text { After that the teacher and students plan a } \\
\text { project to make a collage by determining the } \\
\text { theme to be used. }\end{array}$ & \\
\hline
\end{tabular}




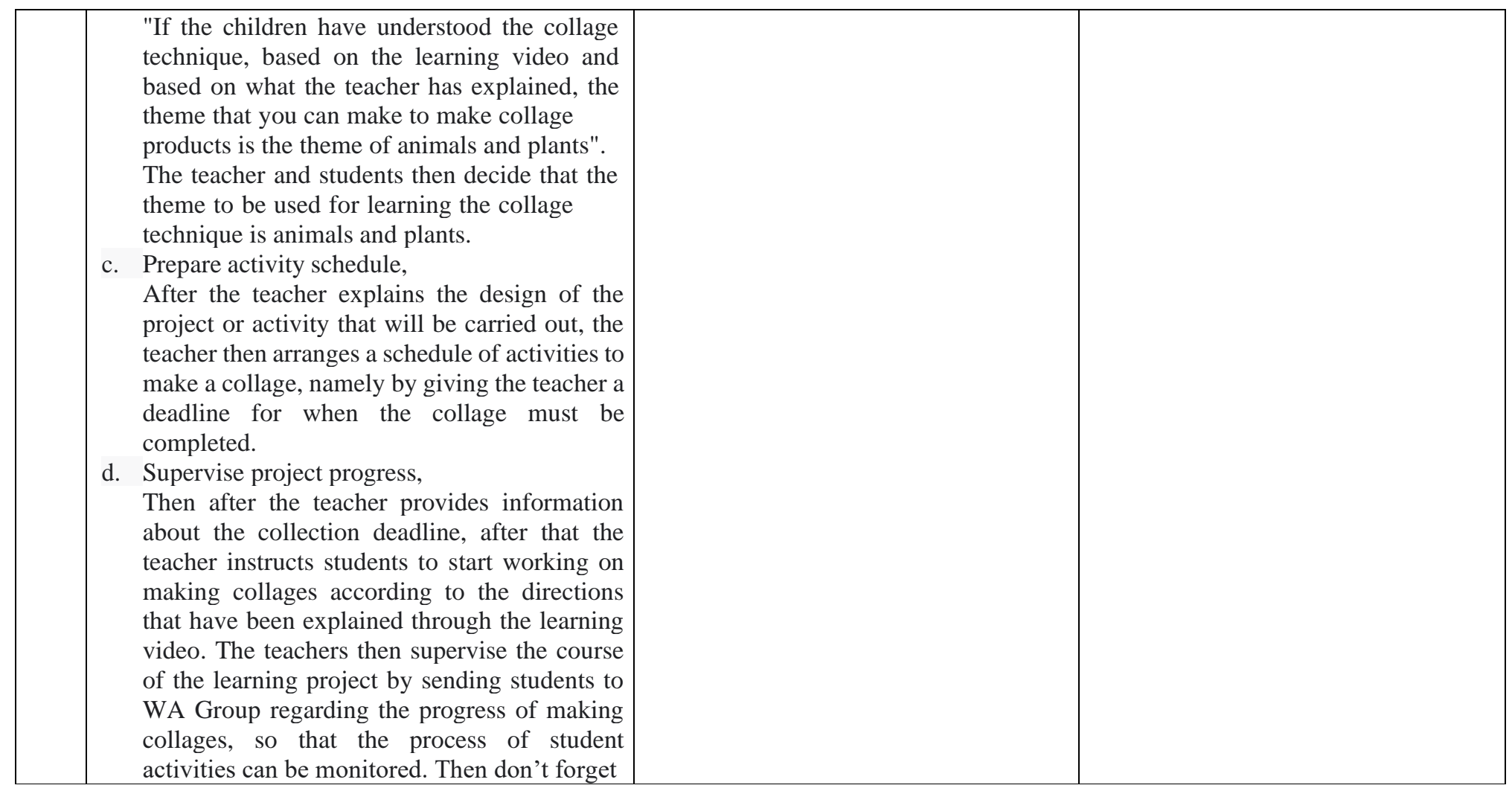




\begin{tabular}{|c|c|c|c|}
\hline & $\begin{array}{l}\text { to ask students if there are difficulties that the } \\
\text { child encounters. } \\
\text { e. Assessment of the resulting product, } \\
\text { In accordance with the predetermined } \\
\text { deadline, then all students collect the results of } \\
\text { their work to make collages by sending the } \\
\text { results by taking photos of their work and then } \\
\text { sending it via WA Group Class IV. After } \\
\text { students start submitting their work, the } \\
\text { teacher begins to evaluate the collage products } \\
\text { that have been made by students based on the } \\
\text { assessment indicators that the teacher has } \\
\text { prepared. So the scoring of students' collage } \\
\text { products can be assessed objectively. } \\
\text { f. Evaluation, } \\
\text { After carrying out the activity of assessing the } \\
\text { results of the collage product of students, then } \\
\text { the teacher conducts an overall evaluation } \\
\text { from the process to the results of the } \\
\text { assessment. And the teacher also provides } \\
\text { comments and input on collage products that } \\
\text { have been produced by students. }\end{array}$ & & \\
\hline 2. & $\begin{array}{l}\text { Using the Learning method Quiz Learning } \\
\text { Method, }\end{array}$ & $\begin{array}{l}\text { a. Mothers prepare a learning } \\
\text { atmosphere in places such as study } \\
\text { rooms, children's rooms or living } \\
\text { rooms that make children comfortable. }\end{array}$ & $\begin{array}{l}\text { a. Stimulate students to think, express } \\
\text { ideas and act creatively, such as the } \\
\text { diversity of students in completing }\end{array}$ \\
\hline
\end{tabular}




\begin{tabular}{|c|c|c|}
\hline $\begin{array}{l}\text { The lesson learned is Theme } 1 \text { material saving } \\
\text { animals and plants, this method is carried out by } \\
\text { chatting in two-way interactive chat groups } \\
\text { between students and teachers. the learning steps } \\
\text { carried out by the teacher: } \\
\text { a. Before learning begins, the teacher opens the } \\
\text { lesson by praying first } \\
\text { "Assalamualaikum Warrahmatullahi } \\
\text { Wabarakatuh" } \\
\text { Morning children, let's before our lesson starts, } \\
\text { start this activity by praying first } \\
\text { b. Next, the teacher asks students questions about } \\
\text { how to save animals and plants as a form of } \\
\text { student readiness to take part in learning. } \\
\text { "What can we do to save endangered } \\
\text { animals?" } \\
\text { c. The teacher chooses the topic to be presented, } \\
\text { namely the material to save living things, then } \\
\text { the teacher explains in advance to students } \\
\text { through learning videos and chatting in groups } \\
\text { about today's learning materials. } \\
\text { d. Delivering to students the quiz delivery format } \\
\text { and the processing system. } \\
\text { So, after choosing the topic to be studied, then } \\
\text { the teacher does not forget to explain the }\end{array}$ & $\begin{array}{l}\text { with the mother conditioning the child } \\
\text { in advance to be ready to follow the } \\
\text { lesson. } \\
\text { "Son, mother has prepared your study } \\
\text { place, what time are you ready to } \\
\text { study?" } \\
\text { b.Provide direction and motivate } \\
\text { children to be active in participating in } \\
\text { learning. } \\
\text { "Pay attention to what the teacher } \\
\text { says, so you can understand what his } \\
\text { job is, okay?" } \\
\text { c. Do not really guide children so that } \\
\text { children can express what their ideas } \\
\text { are, enough to accompany them when } \\
\text { carrying out online learning. }\end{array}$ & $\begin{array}{l}\text { or answering tasks given in various } \\
\text { ways. } \\
\text { b. Children are actively involved in } \\
\text { learning activities. }\end{array}$ \\
\hline
\end{tabular}




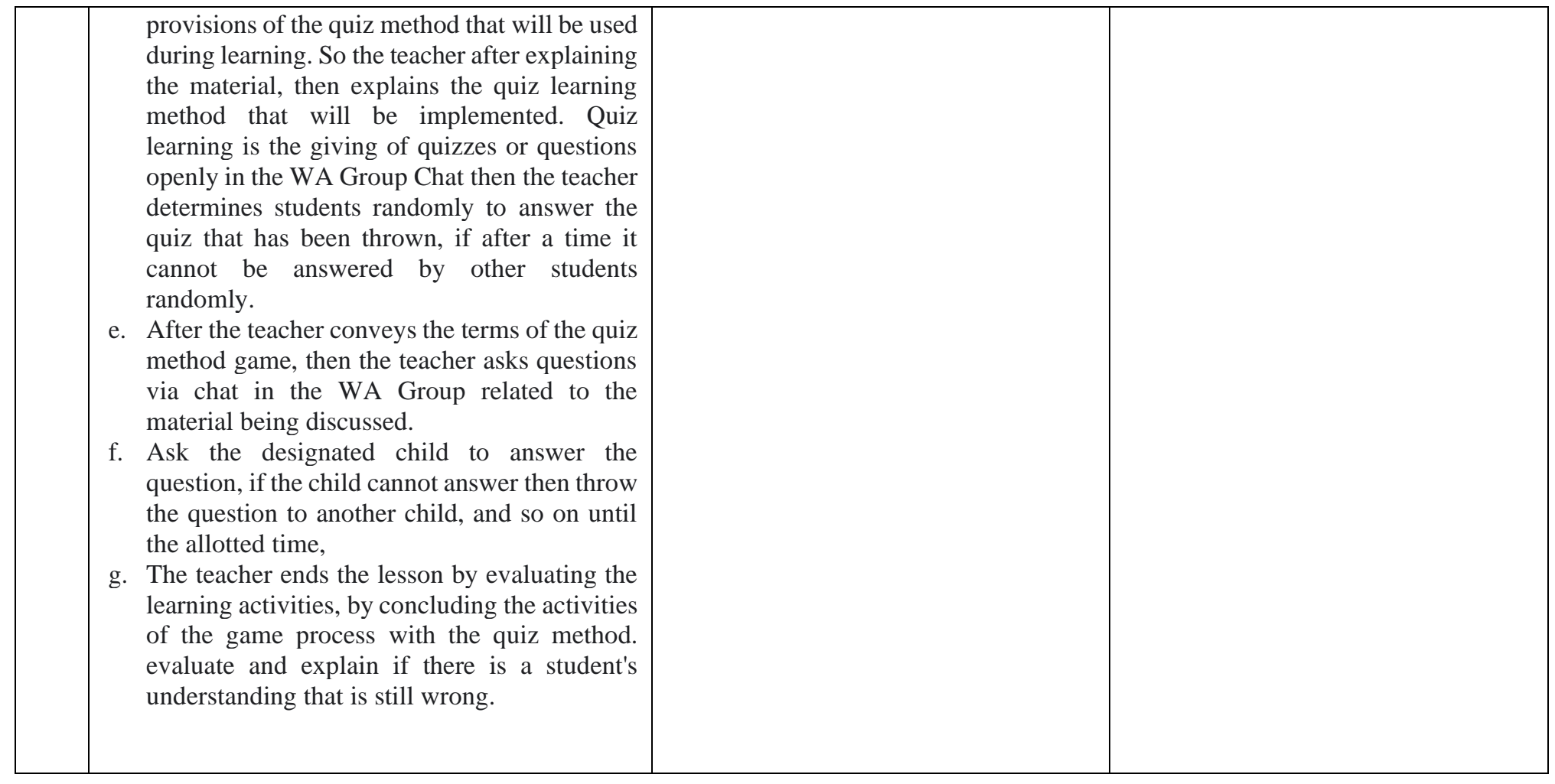


Online learning certainly will not run optimally if there is no role for parents. Therefore, teachers in learning also involve the efforts of parents. Interviews with several parents of students in grades IV and VI, parents' efforts in synergizing with teachers so that students increase creativity are Guiding and preparing children to be ready to take part in learning activities, Providing what children need such as materials and tools for learning media, Providing opportunities to the child to convey what he wants so that we know the purpose of learning so that we can know the learning objectives of the teacher, Provide direction and motivate children to be active in participating in learning, Not too guiding children, so that children can express their own ideas. Parents only need to accompany them as little as possible, Motivate students by giving whatever praise is produced by the child, Train children to plan family activities, Provide a special space for experimenting and make it conducive for children to have a positive attitude towards their environment.

Munandar explained that wise parents can distinguish between paying too much or too little attention, between giving children the opportunity to develop their talents and interests and creativity and putting pressure on them to achieve as much as possible [8]. These conditions can be created if parents themselves show an interest in certain hobbies, to read and provide enough varied reading materials. They take the time to discuss with their children certain readings or problems that occur in their environment. They also seek educational games and tools, stimulate children's creativity.

Parents can make the house a kind of "creativity center" for children, where children alone or with some other friends can be creatively busy. For this reason, a space (not too big) can be provided with a supply of various materials that stimulate children to be creative while being creative, such as various colored paper, books, simple tools, leftover cardboard, bottles, plastic, paint, crayons , musical instruments and so on [9].

\section{Conclusions}

Based on the results of the research and discussion that the authors have described about the efforts of teachers and parents in developing children's creativity through online learning, it can be concluded that the teacher's efforts to develop student creativity are through Project Based Learning (PBL) Methods for fourth grade students. material for making collages with practical learning activities and producing products and interactive quiz learning methods implemented in the WA Group. And don't forget the learning evaluation, namely by providing motivation in the form of rewards or plus values that are informed at the beginning of learning. Then the efforts of parents in synergizing with teachers to develop children's creativity are to direct and accompany children to learn, facilitate learning and what children want. For example in academic learning, parents do not demand children but say democratically, namely asking first, listening to what the child wants, and giving space for children to think and ask what obstacles they face when participating in learning so that children indirectly express what they are looking for. want and continue to motivate them so that children can follow or implement their own ideas. Often good and new ideas are lost because of a loss of confidence or an inability to control oneself.

The creativity of students that emerges through online learning with the synergy of the efforts of teachers and parents in increasing the creativity of students are: a). Students can make various collage model products based on objects and items that are around by pouring their ideas and students' creativity. b). Using varied materials, regardless of what the teacher said. c). Students make collages with different animal themes than usual. If students usually make animalthemes with animals that are around their environment, then there are students who make the Tyrex type Dinosaur animal theme. This shows that their imagination is high and creative. d). 
Students can think, express ideas and act creatively such as the diversity of students in completing or answering tasks given in various ways, e). Children are actively and interactively involved in communication in learning activities. f). Learners are competing to be able to show their ability to get the reward, from their desire the child becomes trying to explore their creativity.

\section{References}

[1] Amalia RR, Anggoro S, Eka KI. Identification of Teachers and Students' Readiness to E-Learning Implementation. JOURNAL OF TEACHING AND LEARNING IN ELEMENTARY EDUCATION (JTLEE); $4(2): 170-9$.

[2] Letter of the Minister of Education and Culture of the Republic of Indonesia Number 3 of 2020 concerning Online Learning

[3] Alwi A. Problem-Based Learning (PBL) as an Assessment Tool in Science Education: A Systematic Review with Exemplars. Learning Science and Mathematics. 2020 Dec 31;15(December):102-to. Soekanto, S. (2002). Role Theory. Jakarta: Bumi Aksara

[4] Kim Y, Park N. The effect of STEAM education on elementary school student's creativity improvement. In Computer applications for security, control and system engineering. 2012 (pp. 115-121). Springer, Berlin, Heidelberg.

[5] Lestari B. Upaya orang tua dalam pengembangan kreatifitas anak. Jurnal ekonomi dan pendidikan. 2006;3(1).

[6] Hamalik O. Teaching and learning process, Jakarta : PT Bumi Aksara. (2009),

[7] Sugiyono, 2017, Qualitative Research Methods, Yogyakarta : CV. Alabeta

[8] Pullias EV, Young JD. A teacher is many things. Indiana University Press; 1968.

[9] Munandar utami, 1999, Developing Talent and Creativity of School Children, Jakarta : PT. Gramedia

[10] Hoffmann J, Russ S. Pretend play, creativity, and emotion regulation in children. Psychology of Aesthetics, Creativity, and the Arts. 2012 May;6(2):175.

[11] Creswell JW, Shope R, Plano Clark VL, Green DO. How interpretive qualitative research extends mixed methods research. Research in the Schools. 2006 Aug;13(1):1-1.

[12] Miles MB, Huberman AM, Saldana J. Qualitative data analysis: A methods sourcebook. 
DOKUMENTASI

Student Activities Make a product collage from objects or items that are around
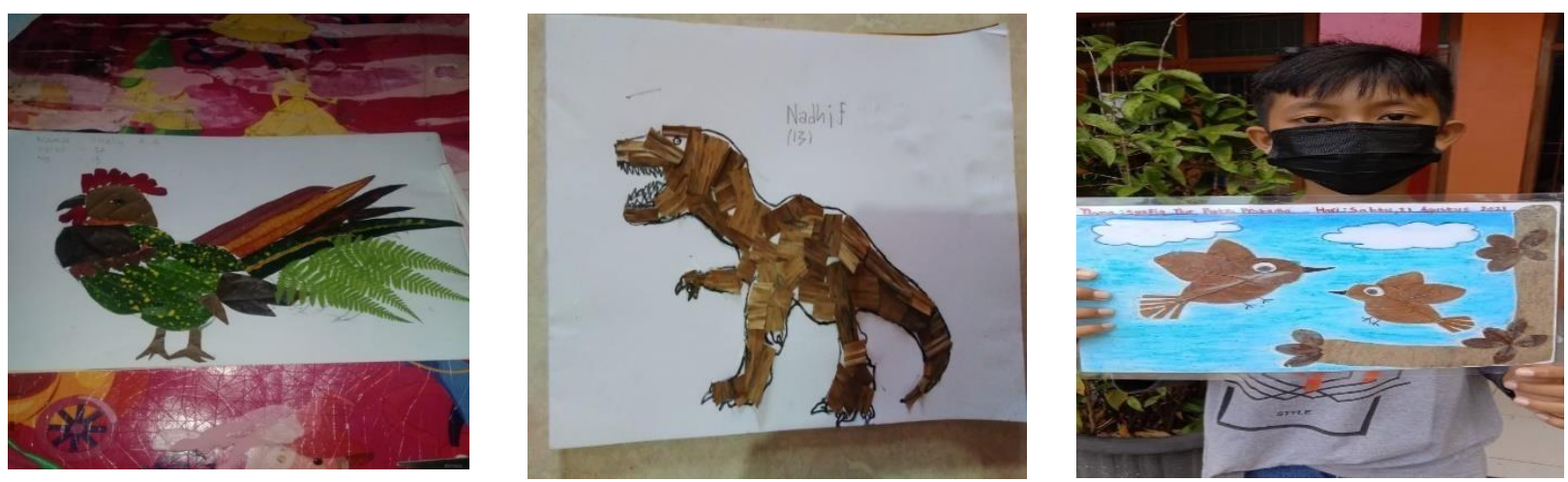

Parents' Efforts in Increasing Children's Creativity
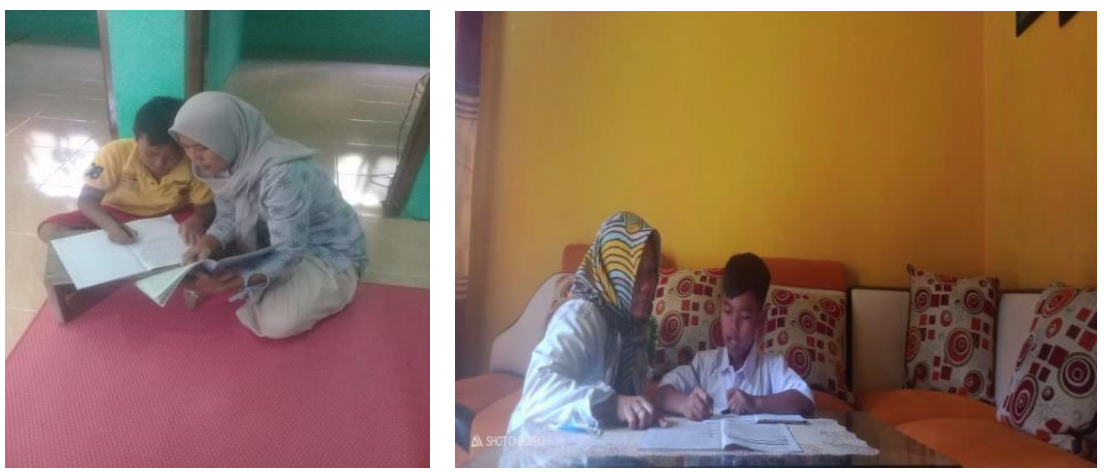